\title{
Modeling Potential Freshwater Ecotoxicity Impacts Due to Pesticide Use in Biofuel Feedstock Production: The Cases of Maize, Rapeseed, Salix, Soybean, Sugar Cane, and Wheat
}

\author{
Maria Nordborg,* Christel Cederberg,* and Göran Berndes \\ Department of Energy and Environment, Division of Physical Resource Theory, Chalmers University of Technology, SE-412 96 \\ Gothenburg, Sweden
}

\section{Supporting Information}

\begin{abstract}
The inclusion of ecotoxicity impacts of pesticides in environmental assessments of biobased products has long been hampered by methodological challenges. We expanded the pesticide database and the regional coverage of the pesticide emission model PestLCI v.2.0, combined it with the impact assessment model USEtox, and assessed potential freshwater ecotoxicity impacts (PFEIs) of pesticide use in selected biofuel feedstock production cases, namely: maize (Iowa, US, two cases), rapeseed (Schleswig-Holstein, Germany), Salix (South Central Sweden), soybean (Mato Grosso, Brazil, two cases), sugar cane (São Paulo, Brazil), and wheat (Schleswig-Holstein, Germany). We found that PFEIs

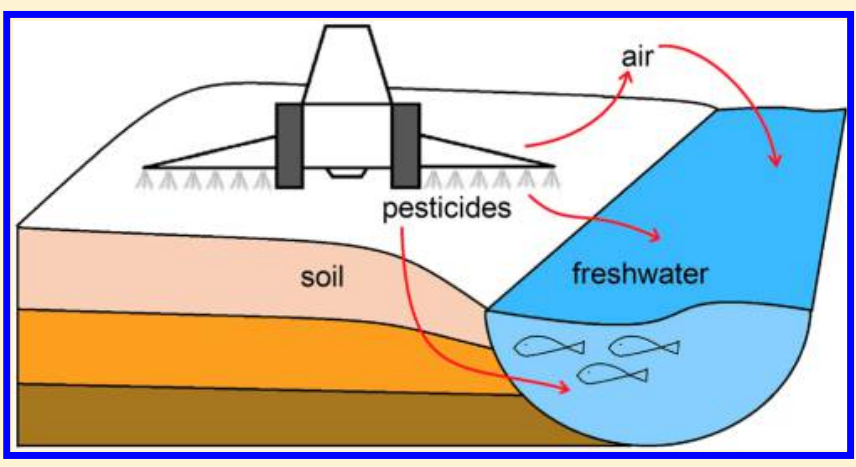
caused by pesticide use in feedstock production varied greatly, up to 3 orders of magnitude. Salix has the lowest PFEI per unit of energy output and per unit of cultivated area. Impacts per biofuel unit were 30, 750, and 1000 times greater, respectively, for the sugar cane, wheat and rapeseed cases than for Salix. For maize genetically engineered (GE) to resist glyphosate herbicides and to produce its own insecticidal toxin, maize GE to resist glyphosate, soybeans GE to resist glyphosate and conventional soybeans, the impacts were 110, 270, 305, and 310 times greater than for Salix, respectively. The significance of field and site-specific conditions are discussed, as well as options for reducing negative impacts in biofuel feedstock production.
\end{abstract}

\section{INTRODUCTION}

The transport sector contributed an estimated $22 \%$ of global $\mathrm{CO}_{2}$ emissions in 2011, ${ }^{1}$ and global demand for transport is expected to grow significantly over the coming decades. The International Energy Agency (IEA) projects that transport fuel demand will grow by nearly $40 \%$ between 2011 and 2035 . $^{2}$ Biomass-based transport fuels (biofuels) currently supply around $3 \%$ of global road transport fuel demand, ${ }^{3}$ a share that is projected to increase significantly in the future, up to $27 \%$ of the total global transport fuel demand by 2050, according to one estimate by IEA. ${ }^{4}$

Most studies of the environmental performance of biofuels have focused on greenhouse gas (GHG) balances, ${ }^{5,6}$ a critical aspect since biofuels are promoted to reduce GHG emissions. However, several studies ${ }^{5,7-12}$ have shown that biofuels can be associated with higher impacts than fossil fuels in terms of, e.g., acidification, eutrophication, ecotoxicity, and human toxicity. Thus, broadening the scope to a wider range of impacts is essential to ensure that conclusions and recommendations are based on sufficiently comprehensive assessments and to avoid environmental burden-shifting. ${ }^{6,9,11,13,14}$

Ecotoxicity impacts due to pesticide use in the cultivation of biofuel feedstocks have received relatively little attention. von Blottnitz and Curran ${ }^{5}$ found that only one of 47 reviewed lifecycle-based studies of ethanol published between 1996 and
2004 considered ecotoxicity. Wiloso and co-workers ${ }^{6}$ found that only six of 31 Life Cycle Assessments (LCAs) of second generation bioethanol published between 2005 and 2011 considered ecotoxicity. Further, inclusion of ecotoxicity in LCA does not necessarily mean that the ecotoxic effects of pesticide use are considered, and contrary; inclusion of pesticides in the inventory does not necessarily mean that ecotoxicity impacts are considered.

Chemical pesticides have become an integral part of agricultural systems since the middle of the last century. ${ }^{15}$ World production of formulated pesticide product increased by approximately a factor 50 between 1945 and 2005. ${ }^{16}$ Since the beginning of the 21 st century, global pesticide consumption has reached a maximum, and currently show a slightly decreasing trend. ${ }^{17-21}$ Pesticides provide many benefits but also have negative effects, such as contamination of surface and groundwater, ${ }^{22}$ and impacts on biodiversity, ${ }^{23}$ community structure and ecosystem function, ${ }^{24}$ pollination services, ${ }^{25}$ and human health. ${ }^{26}$ Large-scale and improper use of pesticides is

Received: May 26, 2014

Revised: September 5, 2014

Accepted: September 10, 2014

Published: September 10, 2014 
Table 1. Definitions of Studied Cases

\begin{tabular}{|c|c|c|c|c|c|c|c|}
\hline case abbrev & feedstock & $\begin{array}{l}\text { biofuel } \\
\text { type }\end{array}$ & cultivation region & $\begin{array}{l}\text { fresh harvest yield } \\
\qquad\left(\mathrm{kg} \mathrm{ha}^{-1} \mathrm{yr}^{-1}\right)\end{array}$ & $\begin{array}{l}\text { biofuel energy yield }{ }^{b} \\
\quad\left(\mathrm{MJ}_{\text {fuel }} \mathrm{ha}^{-1} \mathrm{yr}^{-1}\right)\end{array}$ & $\begin{array}{l}\text { allocation } \\
\text { factor }^{c}\end{array}$ & coproducts considered \\
\hline MZ-I, MZ-II ${ }^{d}$ & maize & ethanol & Iowa, USA & 10700 & 96000 & 0.62 & $\mathrm{DDGS}^{e}$ \\
\hline $\mathrm{RS}$ & $\begin{array}{l}\text { winter } \\
\text { rapeseed }\end{array}$ & biodiesel & $\begin{array}{l}\text { Schleswig-Holstein, } \\
\text { Germany }\end{array}$ & 4050 & 56800 & 0.61 & $\begin{array}{l}\text { rapeseed cake, refined } \\
\text { glycerol }\end{array}$ \\
\hline SX & Salix & ethanol & $\begin{array}{l}\text { South Central } \\
\text { Sweden }\end{array}$ & 20000 & 78800 & 0.94 & electricity \\
\hline SB-I, SB-II ${ }^{f}$ & soybean & biodiesel & Mato Grosso, Brazil & 3030 & 19700 & 0.33 & $\begin{array}{l}\text { soy cake, refined } \\
\text { glycerol }\end{array}$ \\
\hline SC & sugar cane & ethanol & São Paulo, Brazil & 84300 & 154000 & 0.98 & electricity \\
\hline WT & $\begin{array}{l}\text { winter } \\
\text { wheat }\end{array}$ & ethanol & $\begin{array}{l}\text { Schleswig-Holstein, } \\
\text { Germany }\end{array}$ & 8740 & 69600 & 0.56 & DDGS \\
\hline
\end{tabular}

${ }^{a}$ Fresh harvest yields for maize, ${ }^{43}$ rapeseed, ${ }^{44}$ soybean, ${ }^{45}$ sugar cane, ${ }^{45}$ and wheat ${ }^{44}$ represent $2006-2011$ production averages in the defined cultivation regions. The following water contents at harvest were used: maize, $14 \%$; rapeseed, $15 \%$; soybean, $13 \%$; sugar cane, $72.5 \%$; wheat, $13.5 \%{ }^{46}$ Fresh harvest yield for Salix represents a conservative estimate of the future yearly yield potential averaged over a plantation life cycle, assuming $50 \%$ water content at harvest, see SI1.3 (Supporting Information). ${ }^{47}$ Further details on yield data, see SIS (Supporting Information). ${ }^{b}$ Biofuel energy yields refer to the gross biofuel output (i.e., no deduction of energy inputs in biofuel production) per hectare and year from the biofuel conversion plant; more information is available in SIS (Supporting Information). ${ }^{c}$ Allocation factors were calculated using the partitioning method based on energy content considering output shares in representative production systems; ${ }^{46}$ further details are available in SI6 (Supporting Information). ${ }^{d}$ Genetically engineered (GE) glyphosate tolerant maize with (MZ-I) and without (MZ-II) Bt-technology, i.e., ability of the crop to produce its own insecticidal toxin from the bacterium Bacillus thuringiensis. ${ }^{e}$ Dried distillers grains with solubles. ${ }^{f}$ Conventional soybean (SB-I) and GE glyphosate tolerant soybean (SB-II).

also increasingly linked to problems with resistant weeds, insects, and fungi. ${ }^{27-29}$

The amount of applied pesticide active substance (AS) is not an adequate indicator of the ecotoxic effect, an increasingly acknowledged fact. ${ }^{30,31}$ Recent scientific advances, in particular the launch of the USEtox-model ${ }^{32,33}$ for assessment of human toxicity and freshwater ecotoxicity of chemical emissions in Life Cycle Impact Assessment (LCIA), make more sophisticated ecotoxicity impact assessments possible.

The site-generic approach traditionally employed in LCA is less applicable to products of agricultural origin since local agricultural practices and site-specific pedoclimatic factors influence results, ${ }^{7,8,34,35}$ not the least concerning pesticide emissions and toxicity impacts. ${ }^{36,37}$ Pesticide emission fate modeling is currently handled inconsistently in agricultural LCAs, and typically builds upon simplified assumptions and generic fate-factors, ${ }^{38,39}$ e.g., that the pesticide dose is entirely emitted to agricultural soil ${ }^{40}$ or other weakly supported distribution patterns. ${ }^{30,41}$

We combine a state-of-the-art pesticide emission inventory model, PestLCI 2.0, ${ }^{37}$ with the "best available" ${ }^{42}$ model for impact assessment of freshwater ecotoxicity, USEtox, ${ }^{32}$ and assess potential freshwater ecotoxicity impacts (PFEIs) due to pesticide use in cultivation of biofuel feedstocks. Seven cases comprising five conventional feedstock crops are considered (maize, rapeseed, soybean, sugar cane, and wheat), as well as one example of a possible lignocellulosic feedstock for the production of second generation biofuels (Salix: n.b. biofuel conversion technologies not yet commercially available).

The aim of this study is to demonstrate a methodology for PFEI assessment of pesticide use; apply it to a set of biofuel feedstocks; highlight the importance of performing a detailed and site-specific inventory of pesticide usage and emissions; identify the pesticide ASs with highest PFEIs and propose measures to reduce the environmental burden in freshwater ecosystems caused by biofuel feedstock production.

USEtox also allows for the impact assessment of human toxicity, ${ }^{32}$ but the existing method only takes into account the typically minor effects on the general public through diffuse exposure such as airborne emissions, contaminated drinking water, and food residues. The more adverse near-field impacts, affecting primarily field workers through direct exposure, are not taken into account. Toxic effects on humans are therefore not included here.

\section{MATERIALS AND METHODS}

The eight cases included in this study are presented in Table 1 along with their associated cultivation regions, fresh harvest yields, biofuel energy yields, allocation factors, and coproducts.

Functional Units. PFEI scores were determined in relation to (1) hectare (ha) and year (yr) and (2) biofuel yield (joule), i.e., the gross biofuel output per ha and year from the biofuel conversion plant (Table 1). Biofuel energy yields were calculated based on fresh harvest yields, typical transportation pathways, and conversion efficiencies in biofuel conversion plants (SI5, Supporting Information). All biofuels studied can be used as vehicle fuel, thus fulfilling the requirement for equivalent function in LCA.

Pesticide Application Inventory. Crop cultivation practices in the selected regions were investigated, and pesticide application data were obtained from experts familiar with agricultural practices in the respective regions and/or determined on the basis of statistics or other literature, see SI1 (Supporting Information) for more information. The data obtained were complemented or modified, when appropriate, by our own assumptions. Based on this, application scenarios were constructed aiming to represent realistic and typical cultivation practices and pesticide management in the respective regions.

The pesticide application scenarios (SI1, Supporting Information) contain data about the pesticides applied (mass AS per ha and application, i.e., dose), method of application (ground, soil incorporation, or aerial), time of application (month), crop development stage at time of application, tillage type, and average frequency of application. Application frequencies represent the share of fields treated in a year, or the variation between years, and were used to consider major year-to-year fluctuations and even out the pesticide application and resulting PFEI over the years. 
Actual AS chemical formulations were used throughout the study, for example, glyphosate isopropylamine salt (CAS Registry No. (CAS-RN) 38641-94-0) rather than glyphosate (CAS-RN 1071-83-6) as the AS in the herbicide RoundUp Ready. This approach was considered most appropriate in accounting for the potential impact.

Pesticide Emission Modeling. PestLCI v. 2.0.5 ${ }^{37}$ was used to estimate the mass of pesticide AS emitted from the agricultural field to the surrounding natural environment following application. This is the most advanced pesticide emission inventory model developed for use in agricultural LCA currently available. ${ }^{38}$ PestLCI estimates pesticide emissions to air, surface water, and groundwater, by modeling primary and secondary distribution processes following field application. ${ }^{36,37}$ Distribution, transportation, and degradation processes in PestLCI are based on fate modeling principles originating from environmental risk assessment (ERA), with the difference that a realistic estimate of the average mass of AS emitted to the environment is modeled, rather than a worst case predicted environmental concentration (PEC) as in ERA. $^{37}$ Emission distributions are pesticide-, soil-, and climate-specific and depend on a range of field-specific parameters.

The agricultural field down to a depth of $1 \mathrm{~m}$ into the soil and $100 \mathrm{~m}$ up into the air is regarded part of the technosphere, thus excluding emissions to soil. Field data in PestLCI comprise field size (length and width), slope, drainage, depth of drainage system, irrigation, and tillage type and were set in each case based on information from the literature, agricultural experts, and our own assumptions (see SI2, Supporting Information). PestLCI includes seven predefined soil profiles and 25 climate profiles typical in Europe. Climate profiles are defined by the location's monthly averages in terms of air temperature, precipitation, and solar radiation as well as number of days with rainfall, average maximum and minimum air temperatures, yearly potential annual evaporation, and elevation above sea level. Soil profiles are defined by their $\mathrm{pH}-\mathrm{H}_{2} \mathrm{O}$, composition of sand (particles $>50 \mu \mathrm{m}$ ), silt (particles $2-50 \mu \mathrm{m}$ ), clay (particles $<2 \mu \mathrm{m}$ ), and organic carbon content for the various soil horizons, as well as the overall soil bulk density. We developed new site-specific climate profiles and site- and cropspecific soil profiles to represent pedoclimatic conditions in the studied regions (see SI3-SI4, Supporting Information).

The database of PestLCI v. 2.0.5 includes 101 pesticide ASs defined by their molecular mass, water solubility, vapor pressure, dissociation potential, bioaccumulation potential, soil adsorption potential, and degradation rates in soil and atmosphere. We added an additional 31 pesticide ASs to the model database to account for all pesticides identified during inventory (SI11, Supporting Information). PestLCI also enables the evaluation of the effects of buffer zones, i.e., safety areas between field and surface waters where pesticides are not sprayed.

Potential Freshwater Ecotoxicity Impact Assessment. LCIA refers to the assessment of potential impacts by multiplying emissions with so-called characterization factors (CFs), which quantify how much each emission contributes to various environmental impacts, relative to each other. ${ }^{48} \mathrm{We}$ used USEtox v.1.01 $1^{32}$ to calculate PFEIs due to emissions of pesticides to air and surface water. USEtox is an emission routespecific model for comparative assessment of chemicals and their ecotoxic effects on freshwater ecosystems developed for use in LCIA. It was recently appointed "the best" among existing characterization models for freshwater ecotoxicity and human toxicity ${ }^{42}$ and is also recommended by the US Environmental Protection Agency. ${ }^{49}$ No recommended methods exist to date for ecotoxicity impact assessment in the marine and terrestrial compartments. ${ }^{42}$

PFEI scores calculated by USEtox represent an estimate of the potentially affected fraction (PAF) of species in time and freshwater space and are expressed in the unit comparative toxic unit ecotoxicity (CTUe). CFs for ecotoxicity (expressed in the unit CTUe per $\mathrm{kg}$ of a chemical emitted) are available for various emission compartments on the continental and global scales for nearly 2500 substances. ${ }^{50}$ Here, CFs for emissions to continental air and continental freshwater were multiplied with pesticide emissions to air and surface water, respectively.

CFs are products of a fate, an exposure, and an effect factor, in accordance with the relationships that link emissions to impacts in the environment. ${ }^{32}$ Fate factors are calculated on the basis of substance-specific physicochemical properties in combination with site-generic landscape parameters. Exposure factors equal the dissolved fraction and represent the bioavailable share. Effect factors are based on the geometric mean of EC50 and LC50 data for species at different trophic levels in the ecosystem. ${ }^{51}$ CFs are classified as "recommended" or "interim", where the latter indicate that there is a lack of data or considerable uncertainties in the modeling of fate, exposure and/or effect. We derived new CFs for an additional $20 \mathrm{ASs}$, following the recommended procedure, ${ }^{51}$ to account for all substances identified in the inventory. A detailed account how new CFs were derived, and the data used, is presented in SI12SI14 (Supporting Information). It should be noted that USEtox CFs are site-generic and that the site specificness referred to here is limited to the inventory of pesticide usage and emissions.

Allocation. All biofuel production processes considered here are associated with coproducts (Table 1). We applied allocation through partitioning based on energy content as suggested by the EU Renewable Energy Directive (RED) $2009 / 28 / \mathrm{EC}^{52}$ on PFEIs expressed in relation to biofuel yield, while impacts expressed in relation to cultivated area and time were left unallocated. The rationale for not allocating impacts expressed in relation to ha and year is that we considered it more relevant, from the perspective of freshwater ecosystems and their protection, to account for the total impact at the cultivation stage. However, recalculation to allocated results can be done using the allocation factors in Table 1 . The substitution method by system expansion was not considered appropriate since the eight cases are parts of interlinked systems of fuels and feed, making the system expansion method speculative by requiring assumptions about product displacement that have weak empirical support and are sensitive to changes in policy, markets, and production systems. Allocation is a debated topic in LCA, ${ }^{53}$ and other valid bases for partitioning exist, e.g., economic value, although variable over time. Allocation factors (Table 1) were calculated based on output shares in typical production systems, see SI6 (Supporting Information) for more information.

Sensitivity Analyses. A number of parameters that we identified as uncertain or subject to large temporal or spatial variation were tested in sensitivity analyses, in order to quantitatively measure their effects on results. In particular, we analyzed the effects of field size, buffer zones, method of application, soil parameters, and site, on pesticide emissions to air and surface water, and hence PFEI scores, in selected test 
cases. This was done by varying one parameter at a time while keeping all other parameters constant.

\section{RESULTS AND DISCUSSION}

Pesticide Application Rates. Total average pesticide application rates per case vary by more than a factor of 20 , see SI1.7 (Supporting Information). The perennial crop Salix is associated with substantially lower pesticide use than the other crops; fungicides and insecticides are not used at all, and herbicides are, on average, applied only once every third year. In all annual crops except maize, all three major pesticide groups (herbicides, fungicides, and insecticides) are used every year. Insecticides are not applied in MZ-I (Bt-maize) due to the crop's ability to produce its own insecticidal toxin.

Pesticide application rates per AS vary by almost 3 orders of magnitude, while AS-specific PFEI scores vary by 6 orders of magnitude, indicating that amount of pesticide AS applied is an inadequate indicator of ecotoxicity. Glyphosate isopropylamine salt, e.g., is applied at a rate almost 300 times higher than betacyfluthrin in RS; despite this, beta-cyfluthrin causes a PFEI more than 500 times higher than glyphosate isopropylamine salt per application.

Potential Freshwater Ecotoxicity Impacts. PFEI scores vary significantly across the different cases, up to 3 orders of magnitude (Figure 1). Placed in relation to biofuel yield, the SX

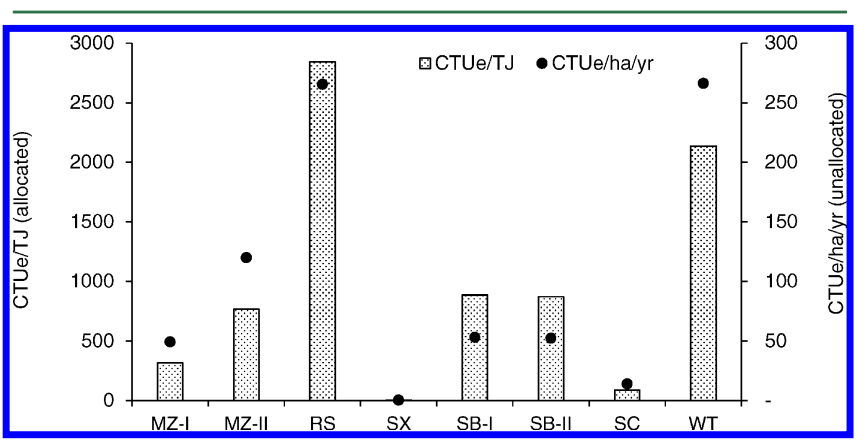

Figure 1. Potential freshwater ecotoxicity impacts in comparative toxic units ecotoxicity (CTUe) per biofuel gross energy output (allocated) and per ha and year of cultivated crop (unallocated). MZ-I, MZ-II: ethanol from genetically engineered (GE) glyphosate tolerant maize with (MZ-I) and without (MZ-II) Bt-technology cultivated in Iowa, USA. RS: biodiesel from winter rapeseed cultivated in SchleswigHolstein, Germany. SX: ethanol from Salix short rotation woody coppice cultivated in South Central of Sweden. SB-I: biodiesel from conventional soybean cultivated in Mato Grosso, Brazil. SB-II: biodiesel from GE glyphosate tolerant soybean cultivated in Mato Grosso, Brazil. SC: ethanol from sugar cane cultivated in São Paulo, Brazil. WT: ethanol from winter wheat cultivated in SchleswigHolstein, Germany. For further details on cases, see SI1 (Supporting Information).

case has a PFEI of about $3 \mathrm{CTUe} \mathrm{TJ}^{-1}$ (allocated value), while impact scores for the cases SC, MZ-I, MZ-II, SB-II, SB-I, WT, and $\mathrm{RS}$ are about $30,110,270,305,310,750$, and 1000 times larger, respectively. In relation to area and time, the SX case has a PFEI of $<1 \mathrm{CTUe} \mathrm{ha} \mathrm{Cr}^{-1}$ (unallocated value), while impact scores for the cases SC, MZ-I, SB-II, SB-I, MZ-II, RS, and WT are about $60,205,220,220,500,1110$, and 1115 times larger, respectively. The favorable result for Salix is explained by the relatively low pesticide use in cultivation, both in terms of application rate $\left(0.24 \mathrm{~kg} \mathrm{AS} \mathrm{ha}^{-1} \mathrm{yr}^{-1}\right)$ and frequencies of application (see SI1.7, Supporting Information), and the use of pesticides (glyphosate isopropylamine salt, flurtamone and diflufenican) with relatively low CFs (see SI7, Supporting Information). Considering that biofuels from lignocellulosic crops are not yet commercially available, the results for Salix should be interpreted as an indication of the future potential.

WT and RS are associated with significantly higher PFEIs than the other cases (Figure 1). The high scores are associated with the use of the fungicide chlorothalonil in WT and the insecticide beta-cyfluthrin in RS, responsible for 84 and $92 \%$ of the total impact scores, respectively, see Table 2 (for an

Table 2. Pesticide ASs with the Largest ( $\geqslant 10 \mathrm{CTUe} \mathrm{ha}^{-1}$ $\mathrm{yr}^{-1}$ ) PFEIs, Identified Here ${ }^{a}$

\begin{tabular}{|c|c|c|c|}
\hline \multicolumn{4}{|c|}{$\begin{array}{c}\text { active substances with an unallocated PFEI } \geq 10 \mathrm{CTUe} \mathrm{ha}^{-1} \mathrm{yr}^{-1} \text { and } \\
\text { corresponding PFEI in CTUe TJ }\end{array}$} \\
\hline pesticide $A S^{b}$ & CTUe $\left(\mathrm{ha}^{-1} \mathrm{yr}^{-1}\right)$ & CTUe $\left(\mathrm{TJ}^{-1}\right)$ & case $^{c}$ \\
\hline beta-cyfluthrin (I) & 244 & 2620 & RS \\
\hline chlorothalonil (F) & 223 & 1793 & WT \\
\hline chlorpyrifos (I) & 71 & 453 & MZ-II \\
\hline atrazine $(\mathrm{H})$ & 44 & 279 & MZ-I/II \\
\hline methomyl (I) & 20 & 327 & SB-I/II \\
\hline lambda-cyhalothrin (I) & 18 & 145 & WT \\
\hline dimethanamid-P $(\mathrm{H}) \times$ & 18 & 188 & RS \\
\hline lambda-cyhalothrin (I) & 17 & 281 & SB-I/II \\
\hline
\end{tabular}

${ }^{a}$ An extended version of Table 2 with pesticide ASs with an unallocated $1 \leq$ PFEI $<10$ CTUe ha ${ }^{-1} \mathrm{yr}^{-1}$ is available in SI15 (Supporting Information). ${ }^{b}$ Pesticide ASs that did not originally have USEtox CFs, but that we calculated, are marked with $\times$. $\mathrm{H}=$ herbicide, $\mathrm{F}=$ fungicide, $\mathrm{I}=$ insecticide. All these ASs all have "recommended" CFs (SI7, Supporting Information). ${ }^{c}$ MZ-I, MZ-II: Genetically engineered (GE) glyphosate tolerant maize with (MZ-I) and without (MZ-II) Bt-technology cultivated in Iowa, USA. RS: winter rapeseed cultivated in Schleswig-Holstein, Germany. SB-I: conventional soybean cultivated in Mato Grosso, Brazil. SB-II: GE glyphosate tolerant soybean cultivated in Mato Grosso, Brazil. WT: winter wheat cultivated in Schleswig-Holstein, Germany. For further details, see SI1 (Supporting Information).

extended version of Table 2, refer to SI15, Supporting Information). The emission pathways via air are responsible for over $98 \%$ of the total impact scores for both substances, but the emission fractions to air are not particularly high $(<0.6 \%$ of the applied doses), in line with the fact that both substances are non to moderately volatile. ${ }^{54}$ In the case of beta-cyfluthrin, it is the very high CFs (SI7, Supporting Information) that explain the top position, while in the case of chlorothalonil, it is the relatively high dose $\left(0.5 \mathrm{~kg} \mathrm{AS} \mathrm{ha}^{-1}\right)$ in combination with high CFs that explain the result. The facts that both substances are nonpersistent and non vs slightly mobile in soil, and non to moderately volatile, indicate that the high CFs is mainly due to their ecotoxic potency, which is consistent with the fact that both substances are classified as highly toxic to fish and aquatic invertebrates. ${ }^{54}$ Field size is also an important explanatory factor to the high impact scores in the cases of RS and WT, see below.

The results indicate positive effects of using Bt-maize (MZ-I), due to the $B t$-technology that eliminates the need for otherwise commonly used insecticides. The use of the insecticide chlorpyrifos in MZ-II is responsible for the 2.4 times larger impact score of MZ-II compared to MZ-I. In contrast, there is no significant difference between the two soybean cases. The pressure of pests and diseases is high in South American soybean cultivation and the present GE-technology includes only herbicide-tolerant soybean, i.e., insecticides and fungicides 
are used every year regardless of seed technology. It should also be noted that pesticide application in the Brazilian cases (SB-I, SB-II and SC) may be underestimated (see SI1.4 and SI1.5, Supporting Information), indicating that the associated PFEIs are in fact higher.

An intuitive interpretation of the PFEI score follow from the definition of the ecotoxicity unit: CTUe $=\mathrm{PAF} \cdot \mathrm{m}^{3} \cdot$ day. If we e.g. consider 1 ha of wheat (WT) and estimate the potentially affected fraction of freshwater species in a $50 \mathrm{~m}^{3}$ pond over the course of 1 week (for simplicity assuming that all pesticides are applied at the same time), the definition gives that $76 \%$ of the species are potentially affected. The same calculation for 1 ha of sugar cane (SC) gives that only $4 \%$ of the freshwater species are potentially affected.

Uncertainty and Variation. The results depend on hundreds of parameters of physicochemical and pedoclimatic character, with varying uncertainty. It has been shown that for CFs, the most uncertain input parameters are substances' halflives in different environmental compartments, and ecotoxic effect factors that are based on substance-specific ecotoxic effect data. ${ }^{50}$ The uncertainty range of CFs has been determined to 1-2 orders of magnitude; ${ }^{32}$ consequently, a substance with CF $=100$ may not be (but probably is), more toxic than a substance with $\mathrm{CF}=1$. The uncertainty in final impact scores also depends on the uncertainty in emissions, which has not been quantified previously, and is beyond the scope of this study. However, pesticide emissions as given by PestLCI have been shown to be in "acceptable accordance" with results produced by state-of-the-art pesticide risk assessment models. ${ }^{37}$ Therefore, a full-scale, quantitative, uncertainty analysis is not possible at this time.

Perhaps even more significant and probably overshadowing uncertainty ranges is the fact that many of the input parameters display large temporal and/or spatial variability due to natural variations in the real world. This applies especially to pedoclimatic parameters, but also to some physicochemical parameters, such as chemical substances half-lives in soil that can vary significantly depending on, e.g., microbial activity and $\mathrm{pH}^{55}$ Consideration of such variations is highly datademanding and thus impractical in most LCAs. Pesticide application in terms of product choices and doses can also have high variability in time and space and depend on a range of factors that vary between farms, regions and years, such as climate and weather, pressure from weeds, pests and diseases, legislation, certification schemes, and commodity prices. The pesticide application scenarios considered here are based on fairly common pesticides but not designed to represent any sort of national or regional average or to cover all possible alternatives. This approach was considered most appropriate considering limitations set by data availability and quality (see below) and difficulties translating pesticide statistics (if available) into realistic use scenarios.

Site-generic pedoclimatic data are usually used in LCA, if at all considered. We used site- and crop-specific data to improve accuracy and reduce uncertainties compared to conventional emission inventory approaches. However, due to existing uncertainties and model limitations, and the fact that quantitative uncertainty ranges have yet to be determined, results should be interpreted with caution, and foremost be used for ranking, and identifying the substances associated with the largest impacts (Table 2). It is thus not possible to determine at this time if there is any significant difference between, e.g., the RS and the WT case, while the qualitative uncertainty analysis indicate that the SX case (and possibly the SC case) offer potential benefits compared to the other cases. Further, it is clear that improvement measures should be directed at the ASs associated with the largest PFEIs, as identified in Table 2.

Sensitivity Analyses. Previous sensitivity analyses of PestLCI 2.0 for the herbicide MCPA showed that the most influential input parameters concerning emissions to air were field width, solar radiation, and average temperature. ${ }^{37}$ Concerning emissions to surface water the most influential input parameters were soil $\mathrm{pH}$, soil texture, and potential evaporation. We performed sensitivity analyses for additional ASs and evaluated the influence of field size, buffer zones, method of application, soil parameters, and site on pesticide emissions and, hence, PFEI scores.

In line with previous findings, ${ }^{37}$ we found field size (or field width to be more precise) to be a critical parameter for emissions to air and PFEI scores, which is due to the modeling of wind drift in particular and the assumption that the wind always blows in parallel with the field width. ${ }^{56}$ The spray equipment is modeled as moving in parallel to the field length. In effect, pesticides that are applied close to the field border perpendicular to the wind direction are dominating the wind drift emissions. ${ }^{56}$ Hence, mass of pesticide AS emitted, averaged over the entire field area, decreases with increasing field width (if length remains constant), whereas in absolute terms, total emissions to air $(\mathrm{kg})$ are practically invariant under field width (if length remains constant) but increase in proportion to field length (if width remains constant). We used field sizes ranging from 10 to 250 ha to represent typical site- and crop-specific conditions (SI2, Supporting Information), and kept all case fields of the same shape (the length twice the width) and orientation with regard to pesticide application and wind direction to minimize influence due to varying field settings.

We tested the effect of changing the field size in the SB-I case from 250 to $10 \mathrm{ha}$, while maintaining field shape and orientation; i.e., we decreased both width and length by a factor 5. This caused the PFEI to increase by a factor 2.7, due to up to 5 times larger per-ha air emissions on the smaller field (Table SI17, Supporting Information). However, emissions to surface water were practically unaffected since emissions due to runoff are modeled as a function of the applied mass per surface unit. ${ }^{56}$ An intuitive interpretation is that the larger the field, the lower the emissions as a fraction of total mass applied, due to decreased ratio of circumference to area. The significance of field size partly explains why the European cases (RS and WT), where field sizes are set to 10 ha, are associated with relatively higher per-ha impacts than the soybean cases, where field sizes are set to 250 ha. The fact that field sizes vary greatly in reality is one of several reasons why caution should be taken before generalizing the results presented here.

Buffer zones are protective strips of land where pesticides are not sprayed, located between fields and surface water to prevent pesticides from reaching these water bodies. ${ }^{57}$ Fields in PestLCI are modeled to have a ditch containing surface water along one side and a slope that results in runoff to this ditch. ${ }^{56}$ We tested the effect of adding product-specific buffer zones for the 13 highest-impact ASs in the WT, RS, and MZ-II cases, i.e., substances with a PFEI $\geq 1 \mathrm{CTUe} \mathrm{ha} \mathrm{Cr}^{-1}$ (Table 2). Buffer zones extended in the range from 5 to $20 \mathrm{~m}$ for ground application ( $0 \mathrm{~m}$; one substance) to $46 \mathrm{~m}$ for aerial application (one substance), see Table SI18 (Supporting Information). As 
a result of the addition of buffer zones, PFEI scores for the WT, RS, and MZ-II cases were reduced by 68,91 , and $78 \%$, respectively, due to air and surface water emissions associated with the analyzed ASs, reducing on average 76 and $86 \%$, respectively. Experimental research in The Netherlands ${ }^{57}$ on the effect of buffer zones of varying width showed that a $3 \mathrm{~m}$ unsprayed strip of land reduced drift deposition in an adjacent ditch by a minimum of $95 \%$, confirming that buffer zones are indeed effective in protecting aquatic ecosystems.

Method of application is an important parameter for emissions to air. Most pesticides are applied using equipment for ground application; however, on tall crops in the Americas, aircraft are frequently used. We tested the effect of using ground application instead of aerial application on the ASs chlorpyrifos (MZ-II) and trinexapac-ethyl (SC) and found that it brought down air emissions by 37 and $10 \%$, respectively.

A soil sensitivity analysis for three ASs (atrazine, glyphosate, and metazachlor), showed that texture is the most influential parameter concerning emissions to surface water, i.e., composition of sand, silt, and clay (SI8, Supporting Information). Emissions to surface water were 3-4 times lower for a sandy soil with low clay content (>55\% sand and $<20 \%$ clay) compared with soils with clay and sand content $>20 \%$ and $<45 \%$, respectively. This may seem counterintuitive but has been confirmed by others ${ }^{58,59}$ and is explained by the fact that soils with high clay content form macropores upon cracking, which act as shortcut transport routes for pesticides.

Atrazine is the second most widely used herbicide on maize in Iowa ${ }^{43}$ and is included in both maize cases. We evaluated the (combined) influence of pedoclimatic parameters by changing site of the application. When the same atrazine dose was applied to maize cultivated in either of the two Brazilian locations (Mato Grosso or São Paulo) instead of Iowa (keeping all other parameters as in the MZ-I case), the PFEI associated with atrazine increased by on average $70 \%$, primarily due to four times higher air emissions of atrazine in Brazil, compared to Iowa. In fact, air emissions are responsible for two-thirds of the total impact score of atrazine in Brazil, compared to onequarter in Iowa. The increase in air emissions is principally associated with climate parameters and most probably an effect of April temperatures in Brazil being significantly higher than in Iowa (see SI9, Supporting Information), as increased temperatures has been shown to increase the volatilization potential of atrazine. $^{60}$

Examples from the sensitivity analyses demonstrate the importance of taking into account site-, crop-, and field-specific conditions in emission modeling and indicate the large uncertainties inherent in site-generic default fate-factors. Archetypical emission fraction values with high geographic resolution do not reduce the need for comprehensive sensitivity analyses and can give LCA practitioners a false sense of precision. Up to now, the influence of parameters such as soil texture, buffer zones, and method of application have not been easily modeled in LCA.

However, such specific inventories are difficult to develop due to limited data availability. In fact, pesticide use statistics are scarce and seldom disaggregated to the level of different ASs, regions, and crops; rather, they are typically given in highly aggregated form, as in the FAOSTAT database. ${ }^{61}$ The statistics collected regularly by the United States Department of Agriculture (USDA) and made publicly available by the National Agricultural Statistics Service (NASS) ${ }^{43}$ are an exception. USDA NASS data are disaggregated to the level of states, crops, and ASs, while for, e.g., Brazil, such publicly available data do not exist. ${ }^{62}$ Recently, the USDA has decreased the inventory frequency in response to budget cuts; now major field crops are surveyed only every five years, ${ }^{43}$ which seriously limits the potential for up-to-date analysis and monitoring. In terms of site- and crop-specific field data and agronomic practices, availability is even more restricted.

Possibilities for Reducing Impacts in Biofuel Feedstock Production. Choice of pesticide product significantly controls the PFEI, as demonstrated by the large range in CFs associated with the ASs included here (up to 7 orders of magnitude, see SI7, Supporting Information). Where only one AS dominates the impact score, as in the cases of RS and WT (Table 2), possibilities for reducing impacts are straightforward. The insecticide beta-cyfluthrin used in RS against the cabbage stem flea beetle (Psylliodes chrysocephala) could, for example, potentially be substituted to another pyrethroid, e.g., lambdacyhalothrin, alpha-cypermethrin, tau-fluvalinate, or esfenvalerate. ${ }^{63}$ We tested the effect of switching to an equivalent dose of lambda-cyhalothrin ${ }^{64}$ and found that it lowered the PFEI in RS by $85 \%$.

Substitution of chlorothalonil, a broad-spectrum fungicide with a multisite mode of action, ${ }^{29}$ is not as straightforward. Due to recent shifts in sensitivity in Septoria leaf blotch (Septoria tritici), the most important fungal disease on wheat in Germany (SI1.6, Supporting Information), agricultural advisors across Europe now recommend tank mixing with multisite fungicides (e.g., chlorothalonil) to protect important fungicide groups, e.g., azoles, from losing their effect. ${ }^{65}$ Chlorothalonil is considered to have a low risk of causing resistance development. ${ }^{29}$ On this basis, it is likely that the use of chlorothalonil will continue. One possible replacement option is the fungicide mancozeb. ${ }^{63}$

The sensitivity analyses indicate that ecotoxic effects could be reduced significantly if, e.g., buffer zones are used where fields abut surface water and aircraft application is avoided. These measures and others that aim to control pests while reducing risks are already well-known within integrated pest management but, until now, not easily assessed within LCA.

Imposition of buffer zones on agricultural lands raises issues related to private property and economic impacts, and enforcing compliance with legislation mandating buffer zones can be a challenge. ${ }^{66}$ Actively managed, and harvested, streamside zones are an alternative to unmanaged buffer zones. ${ }^{67}$ Studies have shown that some plants that are cultivated along waterways can simultaneously provide both freshwater protection and biomass. ${ }^{68-70}$

The results also indicate that impacts would be lower if biofuels were produced from lignocellulosic crops subject to similar pesticide treatment as in the SX case. As mentioned previously, several studies ${ }^{5,7-12}$ have shown that the production of biofuels can be associated with environmental burden shifting compared to fossil fuels, i.e., a net gain in GHG emissions, at the expense of other environmental impact categories. Biofuels based on intensively cultivated crops (high inputs and yields) can have low GHG (and other) emissions per energy output yet cause high local impacts (e.g., acidification, eutrophication, and ecotoxicity). The cultivation of lignocellulosic perennial crops generally involves less pesticide input than conventional biofuel crops, partly because it is not economically motivated and partly because pestinduced effects tend to be smaller. Studies indicate that advanced biofuels produced from lignocellulosic crops 
requiring less input in the cultivation, can perform better on both per output and per hectare basis, and offer environmental benefits that go beyond GHG emissions. For example, Wiloso and co-workers ${ }^{6}$ reviewed 31 LCAs of second-generation bioethanol and found that in the nine cases where a full comparison was possible the overall environmental impact was consistently lower for ethanol than for a reference conventional fossil oil system. The favorable performance of lignocellulosic crops was confirmed in this study (Salix case). Favorable performance can also be due to the use of lignocellulosic residues and wastes as feedstocks, to which impacts are not allocated. Studies have also shown that integration of lignocellulosic crops into agricultural landscapes can reduce the eutrophication load. ${ }^{71,72}$ However, the pesticide use (and other inputs) might increase in a scenario with increased feedstock prices in which biofuel demand causes higher pressure on land. Higher land pressure and feedstock prices might indirectly cause ecotoxicity impacts due to increased pesticide use as well as further expansion of the agriculture frontier into natural ecosystems. Since agricultural frontiers are concentrated in tropical habitats, a very large number of species can potentially be affected due to pesticide use in these areas, ${ }^{73}$ although ecotoxic effects are far from the only impacts associated with expansion of agricultural frontiers.

GE-technology can potentially bring down pesticide use levels. In the cases of US maize and cotton, Benbrook estimated $^{74}$ that the $B t$-technology has reduced insecticide use by 56 million $\mathrm{kg}$ between 1996 and 2011, while with respect to GE herbicide tolerant crops (soybean, cotton, and maize), herbicide use, in particular glyphosate, has increased by 239 million $\mathrm{kg}$, causing a net total increase of $7 \%$. However, it is uncertain if the positive development in Bt-maize will continue as documented cases of field-evolved resistance in western corn rootworm (Diabrotica virgifera virgifera) against multiple Bttoxins have recently been reported. ${ }^{75,76}$ Also, growing problems with spread of glyphosate resistant weeds resulting from excessive use seriously challenge the potentially positive effect of the GE-technology. ${ }^{77,78}$ Our findings do not indicate a reduced PFEI in GE soybeans compared with conventional.

Future Research. Much remains to be done before ecotoxicity due to pesticide use is routinely included in agricultural LCAs. Of prime importance is expansion of substance databases, a highly challenging task since there are approximately 100000 chemicals in commerce today, including 600 pesticide ASs, and thousands of new chemicals are synthesized every year, ${ }^{15}$ but nonetheless critical in overcoming one of the main barriers. A site-specific approach is needed for impact assessment of chemical emissions, since chemical emissions typically cause local impacts. A regional pesticide emissions model, such as PestLCI, is valuable to LCA practitioners but needs to be expanded beyond Europe and validated against non-European soils and climates, e.g., tropical conditions. With regard to impact assessment, regionalization of USEtox is an active research area. ${ }^{79}$ Employing regionalized CFs would increase the accuracy of ecotoxicity studies, but as indicated in the study by Kounina and colleagues, ${ }^{79}$ probably not significantly change the results.

Present models lack capabilities to account for transformation products; a potentially serious shortcoming that needs further attention. This simplification is especially troublesome for compounds that rapidly degrade into more stable compounds, some of which are more toxic than the parent compound. A recent study showed that the inclusion of transformation products may increase freshwater CFs by up to 5 orders of magnitude. ${ }^{80}$ Also, chemical emissions seldom take place in isolation, and the environment is simultaneously exposed to a mixture of chemicals. Surfactants, a common pesticide ingredient, have, e.g., been shown to increase toxicity of pesticides. ${ }^{81,82}$ Methods that deal with the mixture toxicity of chemicals exist ${ }^{83}$ and have been validated for pesticide mixtures ${ }^{84,85}$ but have yet to be integrated in USEtox.

The physicochemical data used as input to PestLCI and USEtox are currently on the recommendations from the respective development teams, derived from different data sources (see SI11-SI13, Supporting Information). This unfortunate situation, the implications of which have yet to be quantified, needs to be resolved to bridge the gap between inventory and impact assessment and increase consistency between models. Other potential model mismatches also need to be revealed and resolved. ${ }^{38}$

Finally, beyond pesticides and toxicity impacts, research is needed to improve our understanding of trade-offs associated with bioenergy expansion and how integration of bioenergy crops into agricultural landscapes could foster multiple ecosystem services and mitigate impacts from existing crops. $^{86,87}$ Implementation of beneficial integration strategies also requires dissemination tools ${ }^{88}$ to support the broad stakeholder processes that are needed to capture synergies and strike a balance between socioeconomic and environmental objectives.

\section{ASSOCIATED CONTENT}

\section{Supporting Information}

Detailed presentation of cases and data on pesticide application, fields, climate, soil, biofuel yields, physicochemical and ecotoxic effect data, as well as allocation factors and CFs. An account of how CFs were derived and supporting materials for results and sensitivity analyses as described in the text. This material is available free of charge via the Internet at http://pubs.acs.org/.

\section{AUTHOR INFORMATION}

\section{Corresponding Authors}

*E-mail: maria.nordborg@chalmers.se, maria.nordborg@gmail. com. Fax: +46 317721152 .

*E-mail: christel.cederberg@chalmers.se. Tel: +46 7314654 33. Fax: +46 317721152.

\section{Notes}

The authors declare no competing financial interest.

\section{ACKNOWLEDGMENTS}

We would like to thank the following persons and organizations for data provision and consultation: R. Barizon, Brazilian Agricultural Research Corporation, EMBRAPA; O. Cavelett and M. Galdos, the Brazilian Bioethanol Science and Technology Laboratory (CTBE); H. J. Gleser, the Chamber of Agriculture in Schleswig-Holstein; S. Azevedo, The Mato Grosso State Soy and Corn Producers Association (APROSOJA); D. Meyer, Round Table of Responsible Soy; N. Yngveson, Swedish Rural Economy and Agricultural Societies Malmöhus, Sweden; G. Sparovek, University of São Paulo and CTBE, and Manoel Regis Lima Verde Leal, CTBE. A special thanks to T. J. Dijkman, Technical University of Denmark, for modeling support. Financial support from IEA Bioenergy Task 43 is gratefully acknowledged, as well as the valuable comments of three anonymous reviewers. 


\section{REFERENCES}

(1) $\mathrm{CO}_{2}$ Emissions from Fuel Combustion; International Energy Agency (IEA): Paris, 2013.

(2) World energy outlook 2013; International Energy Agency (IEA): Paris, 2013.

(3) Chum, H.; et al. Bioenergy. In IPCC Special Report on Renewable Energy Sources and Climate Change Mitigation; Edenhofer, O., PichsMadruga, R., Sokona, Y., Seyboth, K., Matschoss, P., Kadner, S., Zwickel, T., Eickemeier, P., Hansen, G., Schlömer, S., von Stechow, C., Eds.; Cambridge University Press: Cambridge, 2011: pp 209-332.

(4) Technology Roadmap, Biofuels for Transport; International Energy Agency: Paris, 2011.

(5) von Blottnitz, H.; Curran, M. A. A review of assessments conducted on bio-ethanol as a transportation fuel from a net energy, greenhouse gas and environmental life cycle perspective. J. Cleaner Prod. 2007, 15 (7), 607-619.

(6) Wiloso, E. I.; Heijungs, R; de Snoo, G. R. LCA of second generation bioethanol: A review and some issues to be resolved for good LCA practice. Renewable Sustainable Energy Rev. 2012, 16 (7), 5295-5308.

(7) Kim, S.; Dale, B. E. Life cycle assessment of various cropping systems utilized for producing biofuels: Bioethanol and biodiesel. Biomass Bioenergy 2005, 29 (6), 426-439.

(8) Kim, S.; Dale, B. E. Life cycle assessment of fuel ethanol derived from corn grain via dry milling. Bioresour. Technol. 2008, 99 (12), $5250-5260$.

(9) Bai, Y.; Luo, L.; van der Voet, E. Life cycle assessment of switchgrass-derived ethanol as transport fuel. Int. J. Life Cycle Assess. 2010, 15 (5), 468-477.

(10) Emmenegger, M. F.; Gmünder, S.; Reinhard, J.; Zah, R.; Nemecek, T.; Schnetzer, J.; Bauer, C.; Simons, A.; Doka, A. Harmonisation and extension of the bioenergy inventories and assessment; End Report; EMPA Research Institute: Dübendorf, Aug 2012.

(11) Yang, Y.; Bae, J.; Kim, J.; Suh, S. Replacing gasoline with corn ethanol results in significant environmental problem shifting. Environ. Sci. Technol. 2012, 46 (7), 3671-3678.

(12) Yang, Y. Life cycle freshwater ecotoxicity, human health cancer, and noncancer impacts of corn ethanol and gasoline in the US. $J$. Cleaner Prod. 2013, 53, 149-157.

(13) Guinée, J.; Heijungs, R.; Huppes, G.; Zamagni, A.; Masoni, P.; Buonamici, R.; Ekvall, T.; Rydberg, T. Life cycle assessment: past, present and future. Environ. Sci. Technol. 2011, 45 (1), 90-96.

(14) Laurent, A.; Olsen, S. I.; Hauschild, M. Z. Limitations of carbon footprint as indicator of environmental sustainability. Environ. Sci. Technol. 2012, 46 (7), 4100-4108.

(15) Harrison, P.; Pearce, F. Population, waste and chemicals. In AAAS Atlas of Population and Environment [Online]; Markham, V. D., Ed.; American Association for the Advancement of Science and the University of California Press: Berkeley, 2000; pp 107-118. http:// atlas.aaas.org/index.php (accessed Sep 4, 2014).

(16) Carvalho, F. P. Agriculture, pesticides, food security and food safety. Environ. Sci. Policy 2006, 9 (7-8), 685-692.

(17) Pesticides Industry Sales and Usage - 1994 and 1995 Market Estimates; EPA-733-R-97-002; Office of Prevention, Pesticides and Toxic Substances, United States Environmental Protection Agency: Washington, D.C., 1997.

(18) Pesticides Industry Sales and Usage - 1996 and 1997 Market Estimates; EPA-733-R-99-001; Office of Prevention, Pesticides and Toxic Substances, United States Environmental Protection Agency: Washington, D.C., 1999.

(19) Pesticides Industry Sales and Usage - 1998 and 1999 Market Estimates; EPA-733-R-02-001; Office of Prevention, Pesticides and Toxic Substances, United States Environmental Protection Agency: Washington, D.C., 2002.

(20) Pesticides Industry Sales and Usage - 2000 and 2001 Market Estimates; EPA-733-R-04-001; Office of Prevention, Pesticides and Toxic Substances, United States Environmental Protection Agency: Washington, D.C., 2004.
(21) Pesticides Industry Sales and Usage - 2006 and 2007 Market Estimates; EPA-733-R-11-001; Office of Chemical Safety and Pollution Prevention, United States Environmental Protection Agency: Washington, D.C., 2011.

(22) Arias-Estévez, M.; López-Periago, E.; Martínez-Carballo, E.; Simal-Gándara, J.; Mejuto, J.-C.; García-Río, L. The mobility and degradation of pesticides in soils and the pollution of groundwater resources. Agric., Ecosyst. Environ. 2008, 123 (4), 247-60.

(23) Geiger, F.; Bengtsson, J.; Berendse, F.; Weisser, W. W.; Emmerson, M.; Morales, M. B.; Ceryngier, P.; Liira, J.; Tscharntke, T.; Winqvist, C.; Eggers, S.; Bommarco, R.; Pärt, T.; Bretagnolle, V.; Plantegenest, M.; Clement, L. W.; Dennis, C.; Palmer, C.; Oñate, J. J.; Guerrero, I.; Hawro, V.; Aavik, T.; Thies, C.; Flohre, A.; Hänke, S.; Fischer, C.; Goedhart, P. W.; Inchausti, P. Persistent negative effects of pesticides on biodiversity and biological control potential on European farmland. Basic Appl. Ecol. 2010, 11 (2), 97-105.

(24) Schäfer, R. B.; Caquet, T.; Siimes, K.; Mueller, R.; Lagadic, L.; Liess, M. Effects of pesticides on community structure and ecosystem functions in agricultural streams of three biogeographical regions in Europe. Sci. Total Environ. 2007, 382 (2-3), 272-285.

(25) van der Sluijs, J. P.; Simon-Delso, N.; Goulson, D.; Maxim, L.; Bonmatin, J. M.; Belzunces, L. P. Neonicotinoids, bee disorders and the sustainability of pollinator services. Curr. Opin. Environ. Sustainability 2013, 5 (3-4), 293-305.

(26) Mostafalou, S.; Abdollahi, M. Pesticides and human chronic diseases: Evidences, mechanisms, and perspectives. Toxicol. Appl. Pharmacol. 2013, 268 (2), 157-177.

(27) Heap, I. The International Survey of Herbicide Resistant Weeds, www.weedscience.org (accessed Sep 4, 2014).

(28) Insecticide Resistance Action Committee, IRAC, Website. http://www.irac-online.org/ (accessed Sep 4, 2014).

(29) Fungicide Resistance Action Committee, FRAC, Website. http://www.frac.info/ (accessed Sep 4, 2014).

(30) Audsley, E.; Alber, S.; Clift, R.; Cowell, S.; Crettaz, P.; Gaillard, G.; Hausheer, J.; Jolliet, O.; Kleijn, R.; Mortensen, B.; Pearce, D.; Roger, E.; Teulon, H.; Weidema, B.; van Zeijts, H. Harmonisation of environmental life cycle assessment for agriculture; Final Report concerted action AIR3-CT94-2028, European Commission: Silsoe, 2003.

(31) de Vries, S. C.; van de Ven, G. W.; van Ittersum, M. K.; Giller, $K$. E. Resource use efficiency and environmental performance of nine major biofuel crops, processed by first-generation conversion techniques. Biomass Bioenergy 2010, 34 (5), 588-601.

(32) Rosenbaum, R. K.; Bachmann, T. M.; Gold, L. S.; Huijbregts, M. A. J.; Jolliet, O.; Juraske, R.; Koehler, A.; Larsen, H. F.; MacLeod, M.; Margni, M.; McKone, T. E.; Payet, J.; Schumacher, M.; van de Meent, D.; Hauschild, M. Z. USEtox - the UNEP-SETAC toxicity model: recommended characterization factors for human toxicity and freshwater ecotoxicity in life cycle impact assessment. Int. J. Life Cycle Assess. 2008, 13 (7), 532-546.

(33) USEtox Website. http://www.usetox.org/ (accessed 7 Jan, 2014).

(34) Kim, S.; Dale, B. E. Regional variations in greenhouse gas emissions of biobased products in the United States - corn-based ethanol and soybean oil. Int. J. Life Cycle Assess. 2009, 14 (6), 540546.

(35) Fazi, S.; Monti, A. Life cycle assessment of different bioenergy production systems including perennial and annual crops. Biomass Bioenergy 2011, 35 (12), 4868-4878.

(36) Birkved, M.; Hauschild, M. Z. PestLCI - A model for estimating field emissions of pesticides in agricultural LCA. Ecol. Modell. 2006, 198 (3-4), 433-451.

(37) Dijkman, T. J.; Birkved, M.; Hauschild, M. Z. PestLCI 2.0: a second generation model for estimating emissions of pesticides from arable land in LCA. Int. J. Life Cycle Assess. 2012, 17 (8), 973-986.

(38) van Zelm, R.; Larrey-Lassalle, P.; Roux, P. Bridging the gap between life cycle inventory and impact assessment for toxicological assessments of pesticides used in crop production. Chemosphere 2014, $100,175-181$. 
(39) Rosenbaum, R. K.; Anton, A.; Bengoa, X.; Bjørn, A.; Brain, R.; Bulle, C.; Cosme, N.; Dijkman, T. J.; Fantke, P.; Felix, M.; Geoghegan, T. S.; Gottesbüren, B.; Hammer, C.; Humbert, S.; Jolliet, O.; Juraske, R.; Lewis, F.; Maxime, D.; Nemecek, T.; Payet, J.; Räsänen, K.; Roux, P.; Schau, E. M.; Sourisseau, S.; van Zelm, R.; von Streit, B.; Wallman, $\mathrm{M}$. The Glasgow consensus on the delineation between pesticide emission inventory and impact assessment for LCA. Submitted for publication.

(40) Nemecek, T.; Schnetzer, J. Methods of assessment of direct field emissions for LCIs of agricultural production systems; Agroscope Reckenholz-Tänikon Research Station ART \& ecoinvent Centre: Zürich, Aug 2011.

(41) Schmidt, J. H. Life assessment of rapeseed oil and palm oil. Ph.D. Thesis, Part 3: Life cycle inventory of rapeseed oil and palm oil. Aalborg University, June 2007. http://vbn.aau.dk/files/10388016/ inventory report (accessed Nov 26, 2013).

(42) Hauschild, M. Z.; Goedkoop, M.; Guinée, J.; Heijungs, R.; Huijbregts, M. A. J.; Jolliet, O.; Margni, M.; de Schryver, A.; Humbert, S.; Laurent, A.; Sala, S.; Pant, R. Identifying best existing practice for characterization modeling in life cycle impact assessment. Int. J. Life Cycle Assess. 2013, 18 (3), 683-697.

(43) USDA NASS, United States Department of Agriculture National Agricultural Statistics Service. http://www.nass.usda.gov/ (accessed Jan 7, 2014).

(44) Bodennutzung und Ernte in Schleswig-Holstein 2012; Statistikamt Nord - Statistical Office of Hamburg and Schleswig-Holstein: Hamburg, 2013. https://www.statistik-nord.de/uploads/tx_ standocuments/C_I_C_II_j12_SH.pdf (accessed Dec 19, 2013).

(45) Sistema IBGE de Recuperação Automática, SIDRA. IBGE, Instituto Brasileiro de Geografia e Estatística. Tabela 99. http://www. sidra.ibge.gov.br (accessed Jan 13, 2014).

(46) Assessing GHG default emissions from biofuels in EU legislation. Review of the input database to calculate 'Default GHG emissions', following expert consultation, 22-23 Nov 2011, Ispra (Italy); Scientific and Technical Research Report JRC-76057, Institute for Energy and Transport, Joint Research Centre (JRC), European Commission, Publications Office of the European Union: Luxembourg, 2012.

(47) Short rotation coppice willow - Best practice guidelines; Task 43 Technical Report; International Energy Agency (IEA) Bioenergy: Rotorua, 2012.

(48) International Reference Life Cycle Data System (ILCD) Handbook - General guide for Life Cycle Assessment - Detailed guidance, 1st ed.; Institute for Environment and Sustainability, Joint Research Centre (JRC), European Commission, Publications Office of the European Union: Luxembourg, 2010.

(49) Bare, J. TRACI 2.0: the tool for the reduction and assessment of chemical and other environmental impacts 2.0. Clean Technol. Environ. Policy 2011, 13 (5), 687-696.

(50) Henderson, A. D.; Hauschild, M. Z.; van de Meent, D.; Huijbregts, M. A. J.; Larsen, H. F.; Margni, M.; McKone, T. E.; Payet, J.; Rosenbaum, R.; Jolliet, O. USEtox fate and ecotoxicity factors for comparative assessment of toxic emissions in life cycle analysis: sensitivity to key chemical properties. Int. J. Life Cycle Assess. 2011, 16 (8), 701-709.

(51) Huijbregts, M. A. J.; Hauschild, M. Z.; Jolliet, O.; Margni, M.; McKone, T.; Rosenbaum, R. K.; van de Meent, D. USEtox User manual, 2010. http://www.usetox.org/support/tutorials-manuals (accessed Sept 2, 2014).

(52) Directive 2009/28/EC of the European Parliament and of the Council of 23 April 2009 on the promotion of the use of energy from renewable sources and amending and subsequently repealing Directives 2001/77/EC and 2003/30/EC. Official J. Eur. Union, Legislation 2009, 140, 16-62.

(53) Curran, M. A. Co-product and input allocation approaches for creating life cycle inventory data: A literature review. Int. J. Life Cycle Assess. 2007, 12 (1), 65-78.

(54) Agriculture \& Environment Research Unit, University of Hertfordshire: Herts. The Pesticide Properties DataBase (PPDB). http://sitem.herts.ac.uk/aeru/ppdb/en/index.htm (accessed Aug 12, 2014).
(55) Bending, G. D.; Lincoln, S. D.; Edmondson, R. N. Spatial variation in the degradation rate of the pesticides isoproturon, azoxystrobin and diflufenican in soil and its relationship with chemical and microbial properties. Environ. Pollut. 2006, 139 (2), 279-287.

(56) Dijkman, T. J., Ph.D., Technical University of Denmark, Kgs. Lyngby. Personal communication, 2014.

(57) de Snoo, G. R.; de Wit, P. J. Buffer zones for reducing pesticide drift to ditches and risks to aquatic organisms. Ecotoxicol. Environ. Saf. 1998, 41 (1), 112-118.

(58) Tiktak, A.; Hendriks, R. F. A.; Boesten, J. J. T. I.; van der Linden, A. M. A. A spatially distributed model of pesticide movement in Dutch macroporous soils. J. Hydrol. 2012, 470-471, 316-327.

(59) Jarvis, N.; Larsbo, M.; Roulier, S.; Lindahl, A.; Persson, L. The role of soil properties in regulating non-equilibrium macropore flow and solute transport in agricultural topsoils. Eur. J. Soil Sci. 2007, 58 (1), 282-292.

(60) Burt, G. W. Volatility of Atrazine from Plant, Soil, and Glass Surfaces. J. Environ. Qual. 1974, 3 (2), 114-7.

(61) FAOSTAT, the FAO statistical database; Statistics Division of the Food and Agriculture Organization of the United Nations: Rome. http://faostat.fao.org (accessed Jan 7, 2014).

(62) Meyer, D.; Cederberg, C. Pesticide use and glyphosate resistant weeds - a case study of Brazilian soybean production; Report 809; SIK, The Swedish Institute for Food and Biotechnology: Göteborg, 2010. http://www.sik.se/archive/pdf-filer-katalog/SR809.pdf (accessed Jan 27, 2014).

(63) Yngveson, N.Senior consultant, Swedish Rural Economy and Agricultural Societies Malmöhus, Borgeby. Personal communication, 2014.

(64) LKSH, the Chamber of Agriculture in Schleswig-Holstein. Insektizide in Raps im Herbst - Auflagen. http://www.lksh.de/ fileadmin/dokumente/Landwirtschaft/Pflanze/Pflanzenschutz/ Insektizide/Raps_I_gesamtAuflagen.pdf (accessed Jan 27, 2014).

(65) Septoria tritici in winter wheat; Cereals and oilseeds division (HGCA) of the Agriculture and Horticulture Development Board (AHDB): Warwickshire, 2012.

(66) Sparovek, G.; Berndes, G.; Klug, I. L. F.; Barretto, A. G. O. P. Brazilian agriculture and environmental legislation: status and future challenges. Environ. Sci. Technol. 2010, 44 (16), 6046-6053.

(67) Neary, D. G.; Smethurst, P. J.; Baillie, B.; Petrone, K. C. Water quality, biodiversity and codes of practice in relation to harvesting forest plantations in streamside management zones; CSIRO National Research Flagships Sustainable Agriculture: Australia, Aug 2011.

(68) Börjesson, P.; Berndes, G. The prospects for willow plantations for wastewater treatment in Sweden. Biomass Bioenergy 2006, 30 (5), $428-438$.

(69) Gopalakrishnan, G.; Negri, M. C.; Salas, W. Modeling biogeochemical impacts of bioenergy buffers with perennial grasses for a row-crop field in Illinois. GCB Bioenergy 2012, 4 (6), 739-750.

(70) Skenhall, S. A.; Berndes, G.; Woods, J. Integration of bioenergy systems into UK agriculture - new options for management of nitrogen flows. Biomass Bioenergy 2013, 54, 219-226.

(71) Schmidt-Walter, P.; Lamersdorf, N. P. Biomass Production with Willow and Poplar Short Rotation Coppices on Sensitive Areas-the Impact on Nitrate Leaching and Groundwater Recharge in a Drinking Water Catchment near Hanover, Germany. BioEnergy Res. 2012, 5 (3), 546-562.

(72) Parish, E. S.; Hilliard, M. R.; Baskaran, L. M.; Dale, V. H.; Griffiths, N. A.; Mulholland, P. J.; Sorokine, A.; Thomas, N. A.; Downing, M. E.; Middleton, R. S. Multimetric spatial optimization of switchgrass plantings across a watershed. Biofuels, Bioprod. Biorefin. 2012, 6 (1), 58-72.

(73) Schiesari, L.; Waichman, A.; Brock, T.; Adams, C.; Grillitsch, B. Pesticide use and biodiversity conservation in the Amazonian agricultural frontier. Philos. Trans. R. Soc., B 2013, 368 (1619), 20120378

(74) Benbrook, C. M. Impacts of genetically engineered crops on pesticide use in the U.S. - the first sixteen years. Environ. Sci. Eur. 2012, 24 (1), 1-13. 
(75) Gassmann, A. J. Field-evolved resistance to Bt maize by western corn rootworm: predictions from the laboratory and effects in the field. J. Invertebr. Pathol. 2012, 110 (3), 287-293.

(76) Gassmann, A. J.; Petzold-Maxwell, J. L.; Clifton, E. H.; Dunbar, M. W.; Hoffmann, A. M.; Ingber, D. A.; Keweshan, R. S. Field-evolved resistance by western corn rootworm to multiple Bacillus thuringiensis toxins in transgenic maize. Proc. Natl. Acad. Sci. U.S.A. 2014, 111 (14), $5141-5146$.

(77) Mortensen, D. A.; Egan, J. F.; Maxwell, B. D.; Ryan, M. R.; Smith, R. G. Navigating a critical juncture for sustainable weed management. BioScience 2012, 62 (1), 75-84.

(78) Green, J. M. The benefits of herbicide-resistant crops. Pest Manag. Sci. 2012, 68 (10), 1323-31.

(79) Kounina, A.; Margni, M.; Shaked, S.; Bulle, C.; Jolliet, O. Spatial analysis of toxic emissions in LCA: A sub-continental nested USEtox model with freshwater archetypes. Environ. Int. 2014, 69, 67-89.

(80) van Zelm, R.; Huijbregts, M. A. J.; van de Meent, D. Transformation products in the life cycle impact assessment of chemicals. Environ. Sci. Technol. 2010, 44 (3), 1004-1009.

(81) Sharma, S. D.; Singh, M. Surfactants increase toxicity of glyphosate and 2,4-D to Brazil Pusley. HortScience 2001, 36 (4), 726728.

(82) Lee, H. L.; Kan, C. D.; Tsai, C. L.; Liou, M. J.; Guo, H. R. Comparative effects of the formulation of glyphosate-surfactant herbicides on hemodynamics in swine. Clin. Toxicol. 2009, 47 (7), 651-658.

(83) Backhaus, T.; Faust, M. Predictive Environmental Risk Assessment of Chemical Mixtures: A Conceptual Framework. Environ. Sci. Technol. 2012, 46 (5), 2564-2573.

(84) Belden, J. B.; Gilliom, R. J.; Lydy, M. J. How well can we predict the toxicity of pesticide mixtures to aquatic life? Integr. Environ. Assess. Manage. 2007, 3 (3), 364-372.

(85) Coors, A.; Frische, T. Predicting the aquatic toxicity of commercial pesticide mixtures. Environ. Sci. Eur. 2011, 23:22, 1-18.

(86) Berndes, G.; Börjesson, P.; Ostwald, M.; Palm, M. Multifunctional biomass production systems - an overview with presentation of specific applications in India and Sweden. Biofuels, Bioprod. Biorefin. 2008, 2 (1), 16-25.

(87) Meehan, T. D.; Gratton, C.; Diehl, E.; Hunt, N. D.; Mooney, D. F.; Ventura, S. J.; Barham, B. L.; Jackson, R. D. Ecosystem-Service Tradeoffs Associated with Switching from Annual to Perennial Energy Crops in Riparian Zones of the US Midwest. PLoS One 2013, 8 (11), e80093.

(88) Busch, G. GIS-based tools for regional assessments and planning processes regarding potential environmental effects of poplar SRC. BioEnergy Res. 2012, 5 (3), 584-605. 